\title{
Assessment Methods from Around the World Potentially Useful for Public Transport Projects
}

\author{
Eric Bruun, Consultant, Tuup, Ltd \\ Marianne Vanderschuren, University of Cape Town
}

\begin{abstract}
The financial crisis in 2008/2009 has made many countries aware that public funds need to be managed better. A logical step is to identify methods that thoroughly assess the impacts of infrastructure and service investment. The authors argue that assessments should both identify and use performance indicators related to the 'triple bottom line', i.e. economic, social and environmental impacts.

This paper provides an overview of assessment methods used to evaluate public transport investments. Positive and negative aspects of various assessment tools are identified and discussed. Some developing world examples appear to be more elaborate and appropriate, than developed world examples, including examples from the United States (U.S.). Although the authors conclude that all methods/tools have challenges, they are of the opinion that a broad and inclusive assessment of public transport investment projects is a must and that the narrowly analyzed and ad-hoc investments witnessed around the world should be avoided.
\end{abstract}

Keywords: Public transport, assessment, triple bottom line, project evaluation, multicriteria evaluation

\section{Background}

For millennia, mankind has planned and implemented mega projects. The Ancient Egypt built pyramids, the Roman Empire was famous for its roads and, in Africa, Cecil Rhodes planned and partly implemented the 'Cape to Cairo Railway', that was meant to cross Africa and connect the south to the north.

In modern times, cities are large and have an ever growing number of people (and goods) that need be moved so that the urban economy keeps going. Traditionally, Cost-Benefit Analysis (CBA) was used to assess the implementation of these (public) 
transportation systems. However, various authors have identified challenges around the use of CBA (Howarth, 2003; Vanderschuren et al., 2008; Salling and Leleur, 2011; Beukers et al., 2012).

Recognizing externalities related to the movement of people (and goods), the environment and social benefits of sustainable transportation (i.e. public transport and non-motorized transport) have long been identified - the triple bottom line (economy, environment and society) should be included (UITP, 2009). Public Transport (PT) increases mobility for all, improves economic productivity, improves quality of life, reduces car dependency and, consequently, the need for highway expansions (UITP, 2009). The success of PT, however, is dependent on the attractiveness of the service (Lo et al., 2010).

Assessment techniques are used extensively around the world. Henning et al. (2011) established a benchmarking tool for monitoring sustainable transport in New Zealand, a national level example. As will be elaborated upon later, there are also efforts to further develop or refine existing techniques from development banks, cooperative research organizations and NGOs. The literature also elaborates on the appraisal of user experiences and quality of service (Phillips and Guttenplan, 2003; Hawas et al., 2012; Olivková, 2015; Schiefelbusch, 2015; Godavarthy et al., 2015), the assessment of routes and networks (i.e. Banai, 2006), as well as the appraisal of maintenance investment (i.e. Paterson, 2015).

Although the many different methods tried over the years do aim to carry out a holistic appraisal, including all relevant key performance indicators, in practice it has been proven almost impossible to arrive at a totally reliable and widely accepted single value for PT investment projects (Cascajo and Monzon, 2014). Various countries, therefore, opt to use multiple methods, including a vast variation of indicators. This paper elaborates on PT project assessment methods used around the world and it reflects on the usefulness of these methods.

\section{The Need for Ex Ante Assessment of Proposed Projects}

Practice often displays a rush about which PT project alternatives to consider, as well as the selection of the preferred alternative. However, due diligence is required. PT projects are often amongst the most expensive public works projects done in a province, region or city. The results of these projects will be in place for decades and have a lasting impact on the daily lives of people, the economy and the environment. Therefore, the decision-makers who spend public money on these projects should be held accountable.

There are multiple considerations when assessing PT projects. The first is that there are always opportunity costs. In other words, the money can be used for something else that is also urgent, which becomes a serious issue, especially in poorer countries. Another consideration is that there is now a heightened need to look at the long-term effects of all investments. It is prudent to try to reduce greenhouse gases and energy dependency, and reduce all other negative impacts on non-renewable and natural 
resources. There may also be unintended consequences. So it is also prudent to try to identify and consider these.

While a particular mode may sometimes seem like the obvious choice for a particular context, it needs to be confirmed through a rigorous assessment process. Thus, the purpose of this paper is to provide process guidance, based on practices in a sampling of nations. The next section outlines what the authors believe to be the attributes of a good assessment process and the reasons for their inclusion. The following section highlights project assessment methods used in several nations, including samples from both developed and developing nations with which the authors have personal experience, followed by a Strengths, Weaknesses, Opportunities and Threats (SWOT) analysis of the various assessment methods. The final section suggests some improvements.

\section{Attributes of Good Assessment Methods}

An overall assessment methodology for projects that are not strictly for private use or benefit, as is the case for almost all PT projects, should combine many attributes. What follows is one list, but not necessarily comprehensive:

- Inclusive of multiple goals; Assessments should not ignore any goals that are potentially addressed by a project. The importance of being inclusive cannot be overstated. The list needs to be clearly enumerated so that there are no misunderstandings about what is being considered. All too often analysts reach opposite conclusions about a project alternative because they do not have the same goals in mind.

- Include multi-faceted goals; It is essential that positive and negative impacts on the society and environment, at large, are compared to the expected costs and benefits of the project. National and regional goals need to be balanced with local requirements. Furthermore, the effects on a macroscopic, as well as a microscopic, scale need to be included. In order to be able to address multifaceted goals, it might be necessary to create sub-goals that reflect how well a particular goal is met from the particular perspective of the users, the local community, the region, or the nation.

- Weights the Relative Importance of the Multiple Criteria; There is virtually never a situation when all criteria are equally important. Indeed, sometimes one goal is of overriding importance and any other goals that are achieved are incidental. Even more often, a close decision may turn on a particular project excelling in one area where others are weak. Because various project alternatives typically address a particular goal with different degrees of success, it is extremely helpful to be able to identify which goals are most important and which are less. Closely related is the ability to identify conflicting goals so that the trade-offs between them can be considered. An example is maximizing ridership versus minimizing operating subsidy. 
- Requires measurable objectives to monitor progress of project; Most projects take several years from detailed design to construction. Completion may also take place in phases. Furthermore, it may take some years beyond completion before the full impacts are visible, particularly if some of the goals revolve around land development. Any plan submitted for public funding should specify key performance indicators that measures progress towards objectives that reflect the stated goals of a project. The measurement frequency depends on the goal such that actions can be taken. If insufficient progress is made or progress is made at a much higher than anticipated cost, then a review is conducted and the course of the project may be altered. Even if longer term objective outcomes, like densification, come long after project completion, the trends revealed by a carefully designed measurement program are invaluable to improve future project selection.

- Uses data that is already available or can be collected; In the richer, developed countries, data inputs are of central importance, for example, ridership estimates. These, in turn, require samplings of demographic data, traffic flow data, mode split data, origin-destination data, and so on. If not already on hand, an effort is expended to collect this information. This type of data collection, however, will often be unrealistic, if not impossible, in developing countries. In such cases, project objectives must be based on simpler data, such as spot check traffic and ridership counts, and margins of error for forecasts must be increased accordingly.

- Computationally possible; Methods that are fine, in principle, but cannot be applied in practice, should be rejected. As an example, the Net Present Value (NPV) method can almost always be used successfully by the private sector, since it concerns itself only with costs and benefits that accrue to itself. But NPV often runs into difficulty in public sector decisions. Some of the costs and benefits are incommensurable and an effort must, therefore, be made to turn them into the common basis of money. Yet, some goals like "improving air quality" can have highly contentious values. How to monetize the value of improved health, improved visibility, or improved liveability, for instance? In such cases, the NPV need not be discarded. Instead, it can be reported as a range of values and supplemented by additional indicators for objectives whose measures are not included in the NPV computation. However, caution is required when using the NPV, as larger projects will always look better, although the benefits per unit of investment might be lower than for smaller projects.

- Comprehensible to decision-makers; Even if it is technically and computationally possible to develop a sound decision from a "black box" process, it is highly unlikely that it would be accepted by politicians or board members of a public agency. It requires trust in the institution that performs the process. One decision-maker might believe the results based on the values and perceptions of persons working in the institution, while another quickly rejects them without further investigation, based strictly on opinions of past work. Any good assessment method must reach a balance between computational complexity 
required for meaningful analysis and understandability by those outside the circle of analytical experts.

- Defensible to stakeholders - must identify the incidences of costs and benefits; The public should participate in project selection, since each potential project alternative must reflect community concerns. In particular, the distribution of benefits versus costs, must be identified. Nonetheless, it is not necessary that every single project provide equal benefits to all those who made financial contributions or who bear some of the costs.

- Does not contain overly risky assumptions; There are many unknowns about the future. Thus, using a single forecasted value for key design parameters is risky. For example, the rate of traffic growth (or reduction) depends a great deal on future fuel prices and on the locations where land development concentrates. It is, thus, a good idea to design project alternatives that are robust, meaning that the project viability does not depend on a particular projection. Furthermore, a robust project is such that capacity can be scaled up or down over a substantial range and still be feasible.

- Is not biased towards the short term (except when the life of a project is short term); Ever-increasing concern for selection of projects that promote sustainable development means that the longer term impacts must be included. It is clear that the "transportation-economic" method of using the monetary benefit-cost ratio or NPV, as historically used, makes any monetary or monetized costs or benefits virtually zero after about 30 years, regardless of the discount rate used. However, the best way to remove bias remains controversial as consensus has not been reached in either the practitioner or academic communities.

- National government participation; Financial contribution by the highest level of government is important, for two reasons. The first is that it provides a justification for placing a set of national goals and objectives into projects across the nation. Without it, regional projects may promote cross purposes. Second, national-level taxes raise far more revenue. Their availability is often a sine quo non to even initiate studies. Many regions will be net tax revenue losers for some years, but their turn will come when they initiate projects or their projects reach more expensive phases.

\section{Highlights of Commonly Used Assessment Methods}

\section{Germany}

One of the European nations that have had a mature and extensive assessment method is Germany. Specifically for PT investments, this country developed a benefit/cost method (B/C-ratio in 1976 (Bundesminister für Verkehr, 1996), that is still used today. The method includes costs and (dis)benefits from a government (national, provincial and local), operator and society perspective. 
Federal Government has set financial limits for projects. Small projects are not funded. Furthermore, a province (Bundesland) or municipality requesting national funding, will have to generate a substantial percentage $(50 \%)$ of the funds themselves.

The Federal Government has put strict guidelines together regarding all calculations, including the demand estimates. Criteria and attribute values are prescribed (and updated over time). This guarantees a fair comparison of large and small projects across the whole country. Furthermore, a government employee reviews investment applications at all stages. In many cases, the person requests additional alternatives to be reviewed. Due to the vast experience built up on a national government level, many project requests have been positively influenced during the funding application.

The Federal Government establishes a priority list on an ongoing basis. Projects that will receive funding are selected from the top of the list, depending on the budget available. Once a project has started, it is added to the multi-year funding plan, which guarantees funding until the project is completed. The method has two per curial aspects (although methodologically sound):

1. PT fares are excluded from the calculations, as they are a benefit to the operator but a cost to the user (neutral gains), and

2. The institution applying for funding has the liberty to self-fund aspects of a project, excluding the costs from the prescribed calculations. This improves the $\mathrm{B} / \mathrm{C}$-ratio of a project, moving it up the priority list. The first theoretical argument to allow this is that the local institution obviously believes in the project and is willing to invest more than the prescribed percentage. There must, therefore, be local benefits that are not captured in the current prescribed methodology. By allowing the financial exclusion of costs carried locally, this shortcoming of the method can be addressed. A second argument is that it allows a local government to select aspects of a project that are politically most palatable to fund, as opposed to simply asking the electorate to provide a matching fund to a larger, more diffuse project.

\section{Switzerland}

The National Government of Switzerland has used a social norm regarding PT investment for many decades. The policy is that all citizens should have access to PT, in particular a rail based connection (Nationalrat Schweiz, 1986). National Government, therefore, provides the infrastructure and operating subsidy (if required) for one train per direction at every location in the country. If a province or municipality wants to provide a higher frequency, they are responsible for the additional costs (required subsidy). The Municipality of Zurich, for example, extends this social norm thinking based on demand figures (see Table 1). 
TABLE 1.

Passenger Demand

Thresholds to Justify

Service Levels in

Zurich

\begin{tabular}{|l|l|}
\hline \multicolumn{2}{|c|}{ Criteria in Zürich } \\
$\begin{array}{c}\text { Demand } \\
\text { (Passengers per day) }\end{array}$ & \multicolumn{1}{|c|}{$\begin{array}{c}\text { Supply } \\
\text { (Vehicles) }\end{array}$} \\
\hline 5000 & $1 /$ hour \\
\hline 10000 & $1 / 30$ minutes \\
\hline 15000 & $1 / 20$ minutes \\
\hline 20000 & $1 / 15$ minutes \\
\hline Etc. & Etc. \\
\hline
\end{tabular}

Source: Verkehrsverbund Zürich, 1992

\section{The Netherlands}

Although clearly less ambitious then Switzerland, the Netherlands also has a social norm regarding PT services. Every settlement (small villages) is serviced by three buses a day (morning peak, around noon and evening peak). The National Government is willing to invest in other PT systems. Applications are accepted once a year and an auditing team assesses all applications and develops a priority list. Calculations in the Netherlands are not standardized, as is the case in Germany, making the prioritization process difficult. Relatively small and large projects are presented using various demand modeling tools, which make varying assumptions and use different project assessment theories. However, standardization suggestions in the early nineties and naughts were ignored.

\section{England and Wales}

The United Kingdom (U.K.) Central Government provides rigorous procedures for preparing CBA analyses for all transport projects involving over £20M (U.K. DfT, 2006a). Based on feedback, they modified the procedure to address other costs and benefits difficult to monetize, but they remain a side consideration (U.K. DfT, 2009). These procedures have limited and problematic application for PT projects. In 1986, PT services in the U.K. were privatized. Outside the London Metropolitan region, PT is unregulated and is supposed to run on a commercial basis. Operating subsidies are permissible for lower levels of government, for services, such as rural access and mobility for the disabled. Megaprojects, such as CrossRail, a new $113 \mathrm{~km}$ long network across London, including a $21 \mathrm{~km}$ twin tunnel, would be inconceivable without Central Government support. But, in general, capital support is rare away from London, other than the Network Rail (including some regional railway lines), which is a government owned entity.

Privatizing of rail services raised complex organizational issues. Sharing of rail infrastructure between operating franchises, via coordinated timetabling, regulates services. However, sharing between competitors caused serious problems in its earlier years (Watson, 2001) and can be expected to be problematic any time that a line capacity is approached. 
Should cities and regional planning bodies outside London (known as Passenger Transport Executives and Passenger Transport Authorities) decide that a major investment in other infrastructure projects is warranted, they are supposed to first try to raise any needed external financial investments through commercial sources, in a program known as the Private Finance Initiative, rather than ask the Central Government. This hurdle and other Governmental challenges to attempt creating integrated bus-rail services on competitive grounds have limited PT development. The U.K. government itself recognizes that there is serious public dissatisfaction with the investment decision process (U.K. DfT, 2006b; 2012).

\section{Denmark}

With the support of the Danish Government, researchers at the Technical University of Denmark, and their consortium partners, including on the Swedish side of Copenhagen/ Malmö conurbation, have in the last few years, developed some project alternative assessment and selection tools that address many of the gaps and inadequacies of the historically used methods.

One of the new tools they have developed is Ratio Estimation of Non-Dominated Alternatives (REMBRANDT). It is analogous to the Analytic Hierarchy Process (AHP), a technique for including both quantitative and qualitative factors in the assessment using a similar scale for all. These include both positive impacts and negative impacts, for which the relative importance of each is established by decision-makers through a weighting procedure. Figure 1 shows four different projects (alternatives level) each of which has five different goals (impact level) which, together, form the total benefit from a project. Not shown is a similar hierarchy of costs or negative impacts from these projects. An individual is asked how important or preferred each goal is, relative to each of the other goals, on a scale from 1 to 9. They are further asked how effective each alternative is, relative to each of the other projects in helping to meet this goal, again on a scale of 1 to 9 . In fact, in some cases, actual monetary costs can allow objective ranking on the scale. At the opposite extreme, such as how aesthetic an alternative is, the ranking is highly subjective. 


\section{FIGURE 1. \\ AHP Hierarchy \\ for Benefits from \\ Hypothetical Citywide \\ Transit Project}

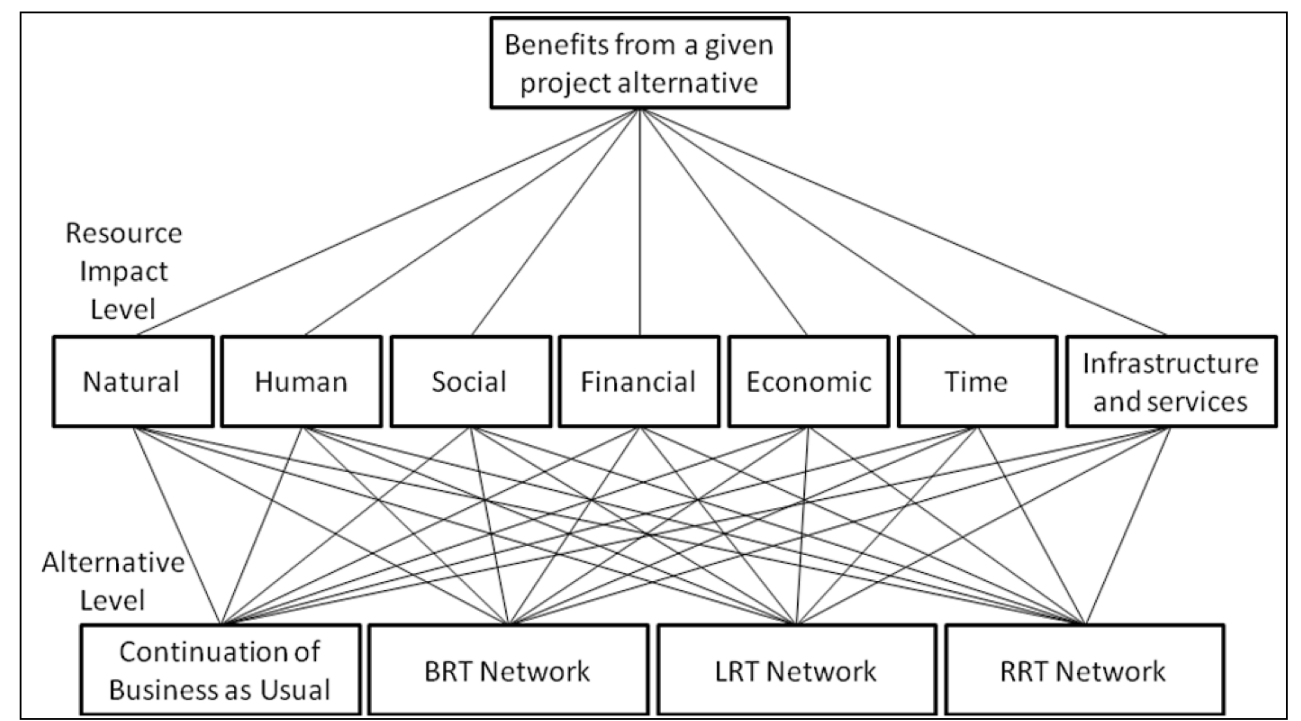

Several project alternatives are analyzed, for their relative effectiveness in maximizing benefits and minimizing costs, by experts. The selected project has the highest ratio of weighted benefits to weighted costs. Although highly intuitive and appealing, it has a few flaws. Some of the practical problems with, and theoretical objections about, AHP have been addressed through a different scoring system. The use of a geometric averaging calculation instead of a weighted linear combination determines the rankings of the various alternatives. Roberts and Goodwin (2002) found that relative weighting of the effectiveness of project alternatives towards meeting a certain goal or objective often tends to follow specific patterns. By using predetermined tables, much of the substantial, and often tedious, efforts needed to establish weights by interviewing individual experts, can be reduced or even eliminated.

The REMBRANDT tool is included in a package of assessment tools known as the SIMDEC (risk SImulation and Multi-criteria decision analysis in combination for DECision support approach). The monetary cost-benefit analysis results are presented in terms of a probability that a specific project alternative will achieve a B/C-ratio greater than 1, resulting in a relative ranking of alternatives. Each important cost and benefit element in the analysis is fitted with a probability distribution to address the uncertainties associated with major infrastructure projects (Salling and LeLeur, 2011; 2012). If an alternative does not have a sufficiently high probability of being feasible, then it can be discarded, even before anything else is considered.

At a decision conference, a software package was demonstrated and applied, showing how a particular individual's own weights of importance of goals varies from others and whether using their individual results alone, instead of the average, would make any difference in project selection outcome. This technique might satisfy public laws and regulations that require the use of $C B A$, as well as individuals and institutions that prefer Multi-Criteria Analysis (MCA).

"It was applied to a real case that concerns an additional crossing between Denmark and Sweden, since the bridge/tunnel that opened in 2000 is already nearing capacity. For more details about this, part of the larger project is known as Oresund EcoMobility, see 
Jensen et al. (2012). For a brief explanation of how the decision conference worked, in this case, see the related presentation (Oresund EcoMobility, 2011).

The research project entitled "SUSTAIN for National Transport Planning (2012-2016)" developed what is now known as the SUSTAIN Appraisal Framework. It provides yet another interesting case study showing the ongoing evolution, involving the TransBaltica Railway corridor, a recently approved high speed rail project linking Tallinn with Warsaw that has huge socio-economic implications (Jensen et al., 2013).

\section{United States of America}

The official U.S. Federal Government assessment procedure for major new projects,

"New Starts", used multiple criteria, as can be seen in Figure 2.

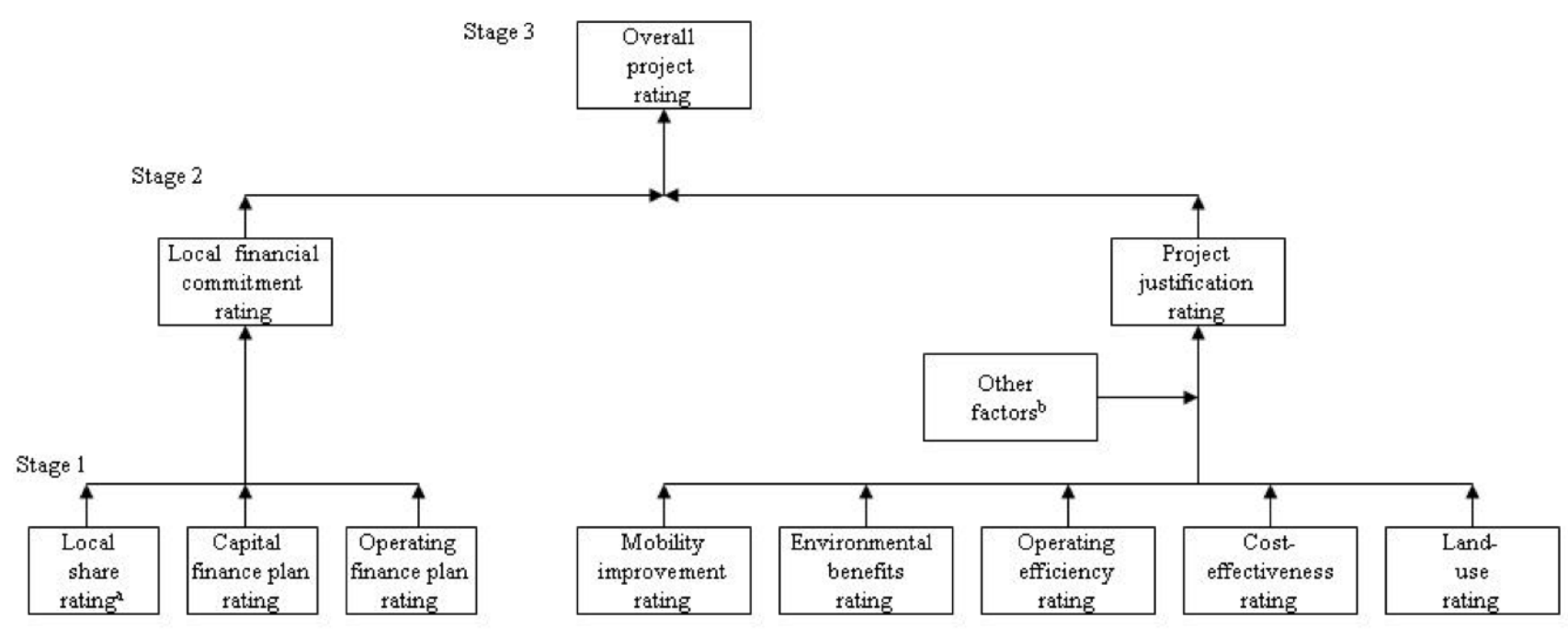

'The local share is the percentage of a project's capital cost to be funded form sources other than new starts funding

bAccording to FTA, this optional criterion gives grantees the opportunity to provide additional information about a project that may contribute to determining the project's overall success

Source: U.S. General Accounting Office, 1999

FIGURE 2. The Federal Transit Administration "New Starts" Assessment and Rating Process

There were two basic categories of assessment:

- The first is whether the local/regional plan includes a credible means of covering its matching fraction of the capital costs, as well as the entire Operating and Maintenance (O\&M) subsidy that may be required.

- The second category is about the cost versus benefit justification of the project. The 'Mobility Improvement' rating reflects time savings to existing users, improved travel for new users and for users of other modes. Environmental 
Benefits rating includes air, water quality, noise reduction and other identifiable impacts. Land Use rating includes densification, farm land and wetland conservation/restoration and other identifiable impacts. Cost Effectiveness rating includes indicators such as: Investment cost per new passenger attracted and Construction cost per unit distance. Operating Efficiency rating excludes the capital element and focuses on indicators like O\&M cost per passenger.

The enabling legislation to create this procedure dates from the Intermodal Surface Transportation Efficiency Act (ISTEA) of 1991. It took almost 8 years to finalize. It remains largely the same today, although some streamlined procedures were later enacted for "Small Starts," in recognition that this highly involved and expensive process was incommensurate in effort with the impacts and cost of minor PT projects.

The assessment process and a recommendation rating are performed by Civil Service staff in the Federal Transit Administration. Although the procedure was certainly designed with the expectation that rail projects would dominate these submissions, it is mode neutral. The actual mode(s) used are decided by the applying entity. It is up to the regional or local authority requesting funding assistance to do its own pre-screening. In the end, one "Locally Preferred Alternative" is submitted. Because of the federal assessment procedure, regions were pressured into some conformity with other regions, with respect to their project justification. The competition for funding is intense and any criterion that might receive a poor review, relative to its peers, stimulates the search for project features that will offset it by outstanding performance in other criteria.

The actual details of the regulations and the authorized funding, for which the applicants compete, is set by multi-year legislation, but the actual level the Congress appropriates, in any given year, may be lower. The SAFETEA-LU Act covered 2005 until 2009. This was followed by 10 extensions continuing funding and programs at existing levels. Then the MAP 21 Act covered the years 2012 and 2013 with some significant changes (AASHTO 2014). A new Act passed with similar funding levels. Many projects at the State level were put on hold during the wait, to the detriment of the construction industry. Such regular delays and changes, and even cancellations to some of the authorized programs from the previous Act, also complicate the assessment process. In December 2015, the Fixing America's Surface Transportation (FAST) Act passed. This is a 5-year authorization so it will lend some stability to both the highway and PT industries and to planning at lower levels of government. But there are few significant changes that affect PT assessment or decrease the intense competition for still-limited funding. In principle, the official U.S. "New Starts" procedure has a lot of merit. Unfortunately, the application of the procedure, over time, has varied. Between 2001 and 2009 the Federal Transit Administration chose to focus only upon the one performance indicator, "net transportation system user benefit", which is capital plus operating cost divided by time saved for both, private vehicles and PT. One year into the next presidential administration, intense lobbying by proposal submitters, restored the method developed under ISTEA (Bell, 2010). The lack of consistent use of an assessment procedure, despite it being legally mandated, reveals that a government might be free to ignore its own rulemaking. Furthermore, political clout by specific lawmakers often 
steered "earmarked" money to favored districts and projects, clearly reducing the objectivity of the procedure. This is in sharp contrast with the long lasting, efficient method adopted and applied in Germany.

\section{Canada}

Canada is an exception amongst the richer, industrially developed countries in that, until about 2005, the Federal Government gave virtually no financial contributions towards PT projects, leaving it up to the provinces and regional/local governments (CUTA, 2011). The result has been a quite wide variation in the level of investment across the country, in general, and a significantly older fleet of vehicles than is seen in its U.S. neighbor.

On the other hand, Canadian cities tend to be more amenable to PT than U.S. cities. The sprawl has not been as severe, due to different tax policies and tighter land use controls, and despite continued population growth. Plus, cities are not as racially and economically segregated, reducing the perceptions of risk and stigma commonly attached to PT in the U.S. This has allowed Canada to operate with higher operating cost recovery factors, in general, than U.S. cities of the same size. In some instances, Toronto for example, under a parsimonious provincial government, some lower operating ratio lines were closed, reducing operating deficits but also service levels. Operating cost recovery rose to between $80 \%$ and $90 \%$. Go Transit, the regional train service, also had a $90 \%$ cost recovery. These are phenomenally high numbers by North American (and even World) standards.

PT support remains sporadic and unpredictable for project planning purposes. In 2003, a substantial but one-time capital assistance of \$CAN 300M was promised from the Federal Government for development of the new Canada Line rail corridor in Vancouver. This was combined with provincial funding to accelerate the investment schedule.

Expansion in Calgary and Edmonton of their Light Rail Transit (LRT) systems was quite slow for decades. In 2010, the Green Trip incentive fund was created by the Province of Alberta. It initially provided \$CAN 2B that could be used for expansion anywhere in the province. It continues today with periodic application deadlines (Alberta Government, 2016). But Alberta remains a special case, due to its oil wealth and, consequently, is much less dependent on the Federal Government.

In Ontario, the same promise of forthcoming federal funding, as seen in Vancouver, gave new impetus to system investment. A new Bus Rapid Transit (BRT) system, Viva, began construction in 2003 and opened in 2005 in York (one of the member cities in the Greater Toronto Area regional planning body). In 2009, a further 37 kilometers of BRT began construction, as well as a 14 kilometer long LRT line (Ministry of Transportation (Ontario), 2009). Since then, an extension of a subway line through Vaughan to York is to be completed by the end of 2017, receiving only about one-third of capital financing from the Federal Government. A three-kilometer spur from a regional line to Pearson International Airport was funded on the condition that it cover its own expenses, thus, requiring a special branded service with a very high fare. It opened in June 2015 but demonstrated very low ridership so the fare was slashed by more than $50 \%$ within six 
months (CBC News, 2016). A large expansion of the streetcar network within Toronto proper, and of the Go Transit regional rail systems, are also in the first stages of design but funding sources are not confirmed.

Montreal is where the consequences of the lack of adequate Federal support can, perhaps, best be seen. Competing uses of limited combined funds over the last decade included choosing between needed extensions of the Metro and additional regional rail lines to improve the limited area coverage, including Trudeau International Airport, versus replacement of antiquated rolling stock and equipment. Despite a new plan to inject \$CAN2.5B over 2015 to 2017, the deferred maintenance and replacement backlog is so huge that the life of some of the metro stock will be extended to more than 60 years (Progressive Railroading, 2014).

The lack of a guarantee of a certain level of funding from the Federal Government, for which the provinces and cities can compete if a formal process is followed, remains an obstacle to long-term investment planning in many urban regions across Canada. It is also clearly contributing to PT systems that are inadequate to cope with population growth. However, after ten years, in 2015 a newly elected national government promised to place a higher priority on environmental concerns, and the entire assessment and funding procedure is now undergoing major revision.

\section{South Africa}

South Africa has a policy and legislative environment that on a national, provincial and local level encourages the integration of all modes and, in fact, prioritizes the needs of PT and non-motorized transport above that of the private automobile. The Act governing land transport in South Africa is quoted as saying (Republic of South Africa, 2000):

"For the purposes of land transport planning and the provision of land transport infrastructure and facilities, public transport must be given higher priority than private transport. Public transport services, facilities and infrastructure must be so provided and developed as to integrate the different modes of land transport".

Due to the lack of all mode inclusive guidelines, current practice relies on old assumptions and, for many engineers, it is business as usual. In some cases, the engineering firms suggest alternative practices to provincial and local government (the implementers of PT projects). An example is the assessment of improved services for the $\mathrm{N} 1$ corridor between Bellville and Cape Town. The project team identified nine different alternatives for PT provision ranging from 'Do Nothing', moderate upgrades of current bus and rail services, to the development of a Busway (Vanderschuren et al., 2008).

Traditionally, Cape Town used CBA for the assessment of transportation projects. The First Edition of the Guidelines for Conducting the Economic Evaluation' of Urban Transport Projects was issued in June 1992 after input from several stakeholders and practitioners. Since then, two reviews have taken place. In May 2002, the city adopted the Third Edition (CCT, 2002). This version allows for the possibility to assess road

${ }^{1}=$ Assessment 
and PT infrastructure investments, as well as interchange facilities. Criteria included are: income distribution considerations, regional developmental benefits (economic developments) and environmental considerations (integration of Environmental Impact Assessment (EIA) requirements).

In order to have confidence regarding the suggested implementation suggestion, the project team decided to step away from the CBA and apply MCA techniques. Different MCA methods have been developed during the last 30 years to support decisionmakers facing conflicting decision situations. An MCA aims to rank or score a finite number of decision options based on a set of assessment criteria. The number of MCA techniques, relevant to developing countries, has increased rapidly over the past several decades (for a recent review see Figueira et al., 2005). They provide practically limitless options for combining weights information with the assessment matrix to attain a result (Hajkowicz and Higgins, 2008). In the Busway example, two different MCA techniques, as well as two different weightings, were applied. The final results are provided in Table 2. As can be seen from the results, the final score can be negative. In the case of a negative score, the overall impact of the alternative will lead to reduced benefits. Implementation is, therefore, not recommended.

A final theory that has been explored in South Africa is the Sustainable Livelihood Approach (SLA). The combined contributions to neighborhood theory of Howard (1898), Perry (1929), Stein and Wright (1929), and Fisher (1984) have provided a rich basis for devising a set of criteria for the planning of sustainable neighborhoods: economic, social, technical and environmental sustainability (Choguill, 2008).

TABLE 2. Summary of the MCA Results for the N1 Busway in Cape Town

\begin{tabular}{|c|c|c|c|c|c|c|c|c|c|c|c|c|c|}
\hline & & \multicolumn{12}{|c|}{ Alternative } \\
\hline & & 0 & 1 & 2 & 3 & 4 & 5 & $6 a$ & $6 b$ & 7 & $8 a$ & $8 b$ & 9 \\
\hline Method & Weight & $\begin{array}{c}\text { Do } \\
\text { nothing }\end{array}$ & $\begin{array}{l}\text { Upgrade } \\
\text { rail }\end{array}$ & $\begin{array}{l}\text { Lane } \\
\text { Balance } \\
\text { to Freeay } \\
\text { Lanes }\end{array}$ & $\begin{array}{c}\text { Lane } \\
\text { Balance \& } \\
\text { Rail } \\
\text { Upgrading }\end{array}$ & $\begin{array}{c}\text { BMT } \\
\text { Lanes \& } \\
\text { Lane } \\
\text { Balance }\end{array}$ & $\begin{array}{c}\text { BMT } \\
\text { Lanes, } \\
\text { Rail } \\
\text { Upgrade } \\
\text { \& Lane } \\
\text { Balance }\end{array}$ & $\begin{array}{c}\text { Busway } \\
\text { \& Lane } \\
\text { Balance }\end{array}$ & $\begin{array}{c}\text { Busway } \\
\text { \& Lane } \\
\text { Balance } \\
\text { (ticket } \\
\text { R3) }\end{array}$ & $\begin{array}{c}\text { Busway, } \\
\text { Rail } \\
\text { Upgrade } \\
\text { \& Lane } \\
\text { Balance }\end{array}$ & $\begin{array}{c}\text { Tram } \\
\text { Train \& } \\
\text { Lane } \\
\text { Balance }\end{array}$ & $\begin{array}{c}\text { Tram } \\
\text { Train \& } \\
\text { Lane } \\
\text { Balance } \\
\text { (ticket } \\
\text { R3.5) }\end{array}$ & $\begin{array}{c}\text { Road } \\
\text { Pricing \& } \\
\text { Lane } \\
\text { Balance }\end{array}$ \\
\hline \multirow{2}{*}{$\begin{array}{l}\text { Weighted } \\
\text { sum }\end{array}$} & Proposed & 0.050 & 0.014 & 0.165 & 0.127 & 0.210 & 0.140 & 0.497 & 0.514 & 0.417 & 0.387 & 0.447 & 0.356 \\
\hline & Initial & 0.039 & -0.011 & 0.137 & 0.084 & 0.180 & 0.095 & 0.431 & 0.454 & 0.329 & 0.301 & 0.381 & 0.296 \\
\hline \multirow{2}{*}{ EVAMIX } & Proposed & -3.469 & -3.848 & -1.485 & -1.892 & -1.125 & -1.967 & 2.981 & 3.191 & 2.027 & 1.841 & 2.561 & 2.086 \\
\hline & Initial & -2.910 & -3.457 & -1.155 & -1.737 & -0.830 & -1.850 & 2.757 & 3.037 & 1.542 & 1.316 & 2.276 & 1.811 \\
\hline
\end{tabular}


Scoones (1998) suggests that the SLA is useful as an umbrella to categorize criteria and attributes, because it acknowledges that, particularly in poor communities, people gain their livelihoods through multiple activities rather than one formal job. In contrast to the previous environment and development thinking aimed at sustainable development, Sustainable Livelihoods is a people-centered paradigm, which emphasizes people's inherent capacities and knowledge and is focused on community level actions (Chambers, 1986; UNDP and Wanmali, 1999). According to Chambers and Conway (1992) (cited in Scoones, 1998):

A livelihood comprises the capabilities, assets (including both material and social resources) and activities required for a means of living. A livelihood is sustainable when it can cope with and recover from stresses and shocks, maintain or enhance its capabilities and assets, while not undermining the natural resource base.

In South Africa, the SLA has been adapted by Barbour and Kane (2003), to include seven resources, which have been included in assessment tools in South Africa and Lesotho (Sah et al., 2008).

The resources applied are:

1. Natural resources, such as fuel consumption and land-use quality;

2. Human resources, such as access to basic services;

3. Social resources, such as neighborhood communication and emergency transport;

4. Financial resources, which includes all the costs related to a project;

5. Economic resources, such as job creation and entrepreneurship;

6. Infrastructure and services; and

7. Time, which includes free time available and independency of children to walk to school without adult supervision.

The move towards MCA and the SLA in South Africa, as demonstrated by various studies and authors has, unfortunately, not led to a change with regards to legal requirements.

\section{Lesotho}

The Kingdom of Lesotho, a land-locked country of about 30,500 km2, with 2.2 million inhabitants, has recently adopted a SLA project assessment tool based, partly, following the South African example but taking the approach to new heights. Lesotho is mountainous over approximately two thirds of its area, where population densities are low. Economic development and survival is a challenge in these areas and, in winter, families are often divided for months as shepherds take their cattle to central points while leaving their wives and children behind. In a case of emergency, access to clinics and hospitals is often not available. Thus, improved rural public transport is important. 
In the literature, the number and type of indicators (criteria), the difficulty of measuring indicators, as well as a lack of data, were identified as technical barriers (May et al., 2008). The question, therefore, arose on how to overcome these challenges in the Lesotho context. An in-depth analysis of government documents and local studies, as well as a review of data sources, led to the adoption of the seven resources identified previously in the South African case. In the final tool, a total of 81 attributes were included, clustered under the seven resources. The attributes were, in some cases, identical to the South African ones. However, there were others, such as soil erosion and access to agricultural land for urban dwellers that were specific to the Lesotho case. Furthermore, All 81 attributes were benchmarked for 8 different geographical area types. In this way, both rural and urban needs can be balanced.

The Lesotho Ministry of Public Works and Transport trusts that the newly developed tool will provide the balance between accessibility issues in rural areas and the need to promote economic development in urban areas. Lesotho Government, as well as the World Bank (sponsor of the project), scrutinized and accepted the tool. The six month practical trial period assisted in fine tuning local requirements.

\section{Other international Assessment Approaches}

The concern for improving assessment procedures is widespread, especially to better take into account longer term sustainability impacts. In 2008, The World Bank issued a policy paper that suggests that it will use a revized assessment method on future urban transport projects. It argues for evaluating such projects, not on a separate basis, but as to how they fit into a "core strategy" that supports broader development goals (Mitric, 2008). Once an initial plan is submitted for funding a particular project, it would be subjected to a set of criteria wider and more long term than simply the readily identifiable and direct economic development benefits. Some of the strategy elements include:

- All transport modes are within the strategy reach;

- Preference for PT modes as the main response to motorization, even when road investments are involved;

- Explicit concern for low-income and poor travelers and communities in both policy and investment dimensions;

- Emphasis on exclusive on-street space for PT trunk lines;

- Preference for public-private partnership (competition-for-the-market regulatory model), with service levels, fares and environmental parameters in public hands; and

- Focused institutional capacity to regulate the PT supply and manage traffic.

Note that this implies an MCA, but the World Bank did not specify that any particular MCA must be used. No doubt loan recipients will be able to submit and defend their own approach appropriate to their particular goals and the level of quantitative information that they have available. 
The Asian Development Bank (ADB) has also made strides in developing a more comprehensive assessment policy that guarantees more consideration of the wider benefits of PT relative to auto-centric projects and whether there are supportive public policies like demand management and land use controls (ADB, 2009).

There are also NGOs offering advice on how to improve the design and selection of urban transport projects. For example, the Sustainable Urban Transport Project (SUTP) examines case study cities and distills some of the best practices into a recommendation for a detailed Sustainable Urban Mobility Plan planning cycle (SUTP, 2014). The Victoria Transport Policy Institute provides suggestions on a better overall approach to multimodal transport project evaluation process based on accessibility instead of mobility (VTPI, 2016a), as well as a "Best Practices Guidebook" focused on a rigorous approach to determining PT benefits and costs in a CBA Analysis.

There are governmental organizations sponsoring research on improving the process as well. For example, the EVIDENCE project of the European Commission (EC) has multiple reports aimed at justifying the values used in CBA and other analyses. One, in particular, comes to the interesting conclusion that there is a list of measures like bike lanes, fare integration, better fare payment technology, real-time passenger information, and so on, that should be done anyway despite (so far) insufficient evidence to economically justify them on their own simply because they are likely to enhance the attractiveness of PT (Shergold and Parkhurst, 2016). Another EC-sponsored project, TIDE, offers a very helpful handbook on how to rigorously incorporate the new wave of transport innovations as possible project alternatives themselves and/or as elements in CBA, as well as an introduction to MCA methods (TIDE, 2013).

Space prohibits discussion of the numerous official methodologies based on CBA in use by governments at all levels. But of particular note is an official guideline from New Zealand, which includes a requirement entitled "Comparison of overseas best practice sustainable development impact assessment" (Abley, et al., 2010). The comparison, unfortunately, is limited to English speaking countries but can serve as a template for a wider comparison of nations that use CBA supplemented with additional factors and/ or MCA. Finally, Holian and McLaughlin (2016) provide a thorough analysis of how the State of California CBA procedure compares with its peers and some local governments and suggests how it might be modified for multi-modal applications.

\section{Highlights from the International Assessment Review}

Every MCA assessment method appears to have advantages and disadvantages. The literature has not come to a conclusion with regards to a preferred method. There are two main schools of thought regarding MCA. The first unifies scores across alternatives, applies a weighting and sums the result per alternative. The second school of thought takes the comparison a step further. After the unification of scores, weighted alternatives are compared pair-wise. It is important to note that different assessment methods might lead to different conclusions. It is also important to note that there isn't even consensus that CBA should be replaced with MCA, especially as CBA methods are including more and more environmental and social criteria. 
In the N1 Corridor project (Vanderschuren et al., 2008) it was decided to use two significantly different methods: The Weighted Sum method (appealing to the first school of thought) and the Evamix method (appealing to the second school of thought) (Vermeulen, 1986). The Evamix approach by Voogd (1982 and 1983), and described in Nijkamp et al., (1990) and Martel and Matarazzo (2005), treats data in the assessment matrix differently, depending on whether it is qualitative (ordinal) or quantitative (cardinal). This is an important contribution of Evamix to MCA. Evamix requires cardinal information on criteria weights. Evamix commences by identifying unique pairs of options. It then determines an ordinal and cardinal dominance score (Hajkowicz and Higgins, 2008). Besides applying two different MCA methods, two different weightings were applied, as well. In all calculations, with both methods, it was concluded that this strengthened the decision- making process.

Some countries, such as Switzerland and, to a lesser extent, the Netherlands, use social norms that guarantee a basic service level of PT for all. Other countries, such as Germany and the U.S., have a long history in using traditional assessment methods (CBA) that are based on a conversion of criteria into monetary terms. One very positive aspect of the process in these countries is the transparency provided. All proposers of new projects use the same set of criteria and values. At the same time, with the enhancements added over the years, the process provides enough flexibility so that circumstances, that are special to a particular location, can be explained and accommodated.

In the German case, it has proven to be extremely valuable to have continued funding guaranteed for a started project, as well as the scheduling of a project in a mediumterm funding plan. Furthermore, the participation of government representatives during all planning stages has increased transparency and comparability of projects country wide.

In some cases, described weaknesses were country specific. In other cases, they were related to the method itself. Table 3 provides an overview of the comprehensiveness and, to some extent, advantages and disadvantages of different explored methods.

MCA and, subsequently, SLA were developed to address shortcomings in existing methods. The fact that disadvantages are reduced in more recently developed methods indicates that they are successful in addressing shortcomings. Although MCA have proven to be useful transport assessment tools, it can be concluded that the SLA is the most holistic and inclusive method described. Specifically, when decision-makers are investing vast amount of taxpayers' money in PT systems that have goals that address the needs of the most vulnerable in the society, decision-making needs to be sound and investment needs to reach as many as possible. This is even more important in developing countries, where financial resources are scarce. 
TABLE 3.

Overview of Different

Basic Assessment

Methods

\begin{tabular}{|c|c|c|c|}
\hline Method & Advantage & Disadvantage & $\begin{array}{l}\text { Country of } \\
\text { Application }\end{array}$ \\
\hline $\begin{array}{l}\text { Cost Benefit } \\
\text { Analysis (CBA) }\end{array}$ & $\begin{array}{l}\text { - Well structured } \\
\text { - One dimension } \\
\text { - Gives economic result } \\
\text { - Sensitivity analysis possible }\end{array}$ & $\begin{array}{l}\text { - Problem converting non- } \\
\text { monetary criteria } \\
\text { - Many calculations to } \\
\text { change everything into a } \\
\text { currency } \\
\text { - Monetary values for } \\
\text { different countries vary } \\
\text { severely } \\
\text { - Discounts costs and } \\
\text { benefits to future } \\
\text { generations }\end{array}$ & $\begin{array}{l}\text { U.S. } \\
\text { Germany } \\
\text { England Wales } \\
\text { Denmark }\end{array}$ \\
\hline $\begin{array}{l}\text { Multi-Criteria } \\
\text { Analysis (MCA) }\end{array}$ & $\begin{array}{l}\text { - Qualitative and quantitative } \\
\text { dimensions included } \\
\text { - Weighting of criteria creates } \\
\text { transparency } \\
\text { - Possible to handle vast } \\
\text { amounts of information } \\
\text { - Sensitivity analysis through } \\
\text { change of weighting }\end{array}$ & $\begin{array}{l}\text { - No direct sensitivity analysis } \\
\text { - Different methods might } \\
\text { provide different answers }\end{array}$ & $\begin{array}{l}\text { South Africa } \\
\text { Future World } \\
\text { Bank Funded } \\
\text { projects }\end{array}$ \\
\hline $\begin{array}{l}\text { Sustainable } \\
\text { Livelihood } \\
\text { Approach } \\
\text { (SLA) }\end{array}$ & $\begin{array}{l}\text { - Provides multiple goal } \\
\text { approach } \\
\text { - Qualitative and quantitative } \\
\text { dimensions included } \\
\text { - Weighting of criteria creates } \\
\text { transparency } \\
\text { - Possible to handle vast } \\
\text { amounts of information } \\
\text { - Sensitivity analysis through } \\
\text { change of weighting }\end{array}$ & - No direct sensitivity analysis & Lesotho \\
\hline
\end{tabular}

The majority of assessment tools reviewed in this paper were computer based. Although a black-box approach should be avoided to guarantee transparency, user friendly systems are valuable to decision-makers. A reduction in processing time, as well as a better understanding by users that have not specialized in the field, is provided.

An ironic result of the elaborate procedure required to receive funds from the U.S. Federal Government is that achievement of environmental goals is, at best, delayed and, at worst, prevented. One reason is that many automobile-based master plans are 'grandfathered'. They were approved many years ago and cause little delay once developers have financing arranged. By comparison, major PT projects require 3 to 5 years to reach groundbreaking. The answer is not to remove the environmental study requirement from PT studies, but perhaps to incentivize local governments into canceling master plans that do not adequately consider the environmental bottom line.

The lack of systematic and consistent support from the Federal Government of Canada has hampered the ability to assemble large sums by regional and provincial governments. It is reflected in both bus and rail rolling stock that remains in use for much longer than average for developed countries. This, in turn, raises operating and maintenance costs borne at the local and regional levels, particularly with the bus mode, 
also reducing attractiveness for choice users. It is also reflected in the lateness, relative to their peers, in which large cities like Montreal and Toronto get rail connections to their major airports and the delay of metro extensions in very high demand corridors, like Toronto to York.

\section{Transferring Best Features of Various Methods to Other Countries}

No locality, region or nation can import a complete project assessment method, including criteria and attributes, from other places. There will always be specific issues that must be addressed and existing legal structures that must be respected. Nevertheless, it might well be possible to incorporate many positive features from other places. It is in this spirit that Table 4 has been constructed. It rates the various example nations and the World Bank, discussed in this paper, regarding how well they serve the attributes that the authors' suggested characterized a good assessment method.

TABLE 4. Summary of Criteria and Rating Attributes at the National Level

\begin{tabular}{|c|c|c|c|c|c|c|c|c|c|c|c|}
\hline Category & Country & G & $\mathrm{CH}$ & NL & U.K. & $\begin{array}{c}\text { Dk } \\
\text { SUSTAIN }\end{array}$ & U.S. & CA & $\mathbf{Z A}$ & LS & $\begin{array}{c}\text { World } \\
\text { Bank }\end{array}$ \\
\hline \multirow{3}{*}{ Costs } & Project capital costs & $\mathrm{Y}$ & Y & Y & Y & Y & Y & Y & $\mathrm{Y}$ & $\mathrm{Y}$ & Y \\
\hline & Operational costs & $\mathrm{Y}$ & $\mathrm{Y}$ & $Y$ & $\mathrm{LDN}^{1}$ & $Y$ & $\mathrm{Y}$ & $\mathrm{N}$ & $Y$ & $\mathrm{Y}$ & $\mathrm{Y}$ \\
\hline & Maintenance costs & $\mathrm{Y}$ & Y & Y & $\mathrm{LDN}^{1}$ & Y & Y & $\mathrm{N}$ & $\mathrm{Y}$ & $Y$ & Y \\
\hline \multirow{6}{*}{ Economic } & Job creation & $\mathrm{N}$ & $\mathrm{N}$ & Ps & $\mathrm{N}$ & $\mathrm{N}$ & $\mathrm{N}$ & $\mathrm{N}$ & $\mathrm{Y}$ & $\mathrm{Y}$ & $\mathrm{Y}$ \\
\hline & Job security & $\mathrm{N}$ & $\mathrm{N}$ & Ps & $\mathrm{Ra}$ & $\mathrm{N}$ & $\mathrm{N}$ & $\mathrm{N}$ & $\mathrm{Y}$ & $\mathrm{Y}$ & $\mathrm{N}$ \\
\hline & Entrepreneurship & $\mathrm{N}$ & $\mathrm{N}$ & Ul & $Y$ & $\mathrm{~N}$ & $\mathrm{~N}$ & $\mathrm{~N}$ & $\mathrm{Y}$ & $\mathrm{Y}$ & $Y$ \\
\hline & Tourism & $\mathrm{N}$ & $\mathrm{N}$ & Ps & LDN & Ps & Ps & $\mathrm{N}$ & Ps & $N$ & $\mathrm{~N}$ \\
\hline & Impact on logistics & $\mathrm{N}$ & $\mathrm{N}$ & UI & $\mathrm{N}$ & $\mathrm{Y}$ & $Y$ & Ps & Ps & Ps & $Y$ \\
\hline & Financial wellbeing & $\mathrm{N}$ & $\mathrm{N}$ & Ul & $\mathrm{Ra}$ & Y & $\mathrm{N}$ & $\mathrm{N}$ & Ps & $\mathrm{Y}$ & $\mathrm{N}$ \\
\hline \multirow{6}{*}{ Social } & Social security & $\mathrm{N}$ & $\mathrm{N}$ & UI & $\mathrm{Ra}$ & $\mathrm{N}$ & $\mathrm{Y}$ & $\mathrm{N}$ & Ps & $\mathrm{Y}$ & $\mathrm{N}$ \\
\hline & Equity between regions/provinces & $\mathrm{N}$ & $\mathrm{Y}$ & $\mathrm{L}$ & $\mathrm{N}$ & $\mathrm{Y}$ & $\mathrm{N}$ & $\mathrm{N}$ & $\mathrm{Y}$ & $\mathrm{Y}$ & $\mathrm{Y}$ \\
\hline & Densities and land use & $\mathrm{Y}$ & $\mathrm{Y}$ & Ps & $\mathrm{N}$ & $\mathrm{N}$ & $\mathrm{Y}$ & $\mathrm{N}$ & Ps & $\mathrm{Y}$ & $\mathrm{Y}$ \\
\hline & Emergency services & $\mathrm{N}$ & $\mathrm{N}$ & Ps & LDN & $\mathrm{N}$ & $\mathrm{N}$ & $\mathrm{N}$ & Ps & $\mathrm{Y}$ & $\mathrm{N}$ \\
\hline & Disaster management & $\mathrm{N}$ & $\mathrm{N}$ & Ps & LDN & $\mathrm{N}$ & Ps & $\mathrm{N}$ & Ps & $\mathrm{Y}$ & $\mathrm{N}$ \\
\hline & Communication & $\mathrm{N}$ & $\mathrm{N}$ & $\mathrm{UI}$ & $\mathrm{N}$ & $\mathrm{N}$ & $\mathrm{N}$ & $\mathrm{N}$ & Ps & $\mathrm{Y}$ & $Y$ \\
\hline Legend: & $\begin{array}{l}\mathrm{Y}=\text { Yes } \\
\mathrm{N}=\text { No } \\
\text { LDN = London } \\
\mathrm{Ps}=\text { Project specific } \\
\mathrm{Ra}=\text { Rural areas } \\
\text { Uk = Unknown } \\
\text { UI = Unlikely }\end{array}$ & \multicolumn{3}{|c|}{$\begin{array}{l}E=\text { Excellent } \\
\text { VG = Vary Good } \\
G=\text { Good } \\
F=\text { Fair } \\
P=\text { Poor } \\
\text { VP = Very Poor } \\
L=\text { Likely } \\
\text { N/A = Not Applicable }\end{array}$} & \multicolumn{7}{|c|}{$\begin{array}{l}{ }^{1} \text { Contracting in London, otherwise socially necessary } \\
\text { services only } \\
2 \text { national required, local content not allowed } \\
{ }^{3} \text { pertains to developing countries }\end{array}$} \\
\hline
\end{tabular}


TABLE 4. (Cont'd) Summary of Criteria and Rating Attributes at the National Level

\begin{tabular}{|c|c|c|c|c|c|c|c|c|c|c|c|}
\hline Category & Country & $\mathbf{G}$ & $\mathbf{C H}$ & NL & U.K. & $\begin{array}{c}\text { Dk } \\
\text { SUSTAIN }\end{array}$ & U.S. & CA & $\mathbf{Z A}$ & LS & $\begin{array}{l}\text { World } \\
\text { Bank }\end{array}$ \\
\hline \multirow{12}{*}{ Human } & Road safety & $\mathrm{Y}$ & $\mathrm{N}$ & $\mathrm{L}$ & Y & $\mathrm{Y}$ & Y & Y & Y & $\mathrm{Y}$ & Y \\
\hline & Active transport and health & $\mathrm{N}$ & $\mathrm{N}$ & $\mathrm{N}$ & $\mathrm{N}$ & $\mathrm{Y}$ & $\mathrm{N}$ & $\mathrm{N}$ & $\mathrm{N}$ & $\mathrm{N}$ & $\mathrm{N}$ \\
\hline & Access to basic services & Y & $\mathrm{N}$ & Ul & $\mathrm{Ra}$ & $\mathrm{N}$ & $\mathrm{N}$ & $\mathrm{N}$ & Y & $\mathrm{Y}$ & $\mathrm{Y}$ \\
\hline & Access to agriculture & $\mathrm{N}$ & $\mathrm{N}$ & UI & $\mathrm{N}$ & $\mathrm{N}$ & $\mathrm{N}$ & $\mathrm{N}$ & $\mathrm{Y}$ & $\mathrm{Y}$ & $\mathrm{N}$ \\
\hline & Sense of freedom & $\mathrm{N}$ & $\mathrm{N}$ & UI & $\mathrm{N}$ & $\mathrm{N}$ & $\mathrm{N}$ & $\mathrm{N}$ & Ps & $\mathrm{Y}$ & $\mathrm{N}$ \\
\hline & Transport related fear & $\mathrm{N}$ & $\mathrm{N}$ & UI & $\mathrm{N}$ & $\mathrm{N}$ & $\mathrm{N}$ & $\mathrm{N}$ & Ps & $\mathrm{Y}$ & $\mathrm{Y}$ \\
\hline & Energy use & $\mathrm{Y}$ & $\mathrm{N}$ & $\mathrm{L}$ & $\mathrm{N}$ & $\mathrm{Y}$ & $\mathrm{N}$ & $\mathrm{N}$ & $\mathrm{Y}$ & $\mathrm{Y}$ & $\mathrm{Y}$ \\
\hline & Air pollution & Y & $\mathrm{N}$ & $\mathrm{L}$ & LDN & $\mathrm{Y}$ & Y & $\mathrm{Y}$ & Y & $\mathrm{Y}$ & $\mathrm{Y}$ \\
\hline & Noise pollution & $\mathrm{Y}$ & $\mathrm{N}$ & $\mathrm{L}$ & LDN & $\mathrm{Y}$ & Y & $\mathrm{Y}$ & $\mathrm{N}$ & $\mathrm{N}$ & $\mathrm{Y}$ \\
\hline & Clean water provision & $\mathrm{N}$ & $\mathrm{N}$ & Ps & $\mathrm{N}$ & $\mathrm{N}$ & $\mathrm{Y}$ & $\mathrm{N}$ & UI & $\sqrt{ }$ & $\mathrm{N}$ \\
\hline & Local materials availability & $\mathrm{N}$ & $\mathrm{N}$ & Ul & Y & $\mathrm{N}$ & $Y^{2}$ & $\mathrm{Y}^{2}$ & $\mathrm{UI}$ & $\sqrt{ }$ & $\mathrm{N}$ \\
\hline & Soil erosion & $\mathrm{N}$ & $\mathrm{N}$ & UI & $\mathrm{N}$ & $\mathrm{N}$ & $\mathrm{Y}$ & $\mathrm{N}$ & $\mathrm{UI}$ & $\sqrt{ }$ & $\mathrm{N}$ \\
\hline \multirow{2}{*}{ Time } & Free time available & $\mathrm{N}$ & $\mathrm{N}$ & UI & $\mathrm{N}$ & $\mathrm{N}$ & $\mathrm{N}$ & $\mathrm{N}$ & Ps & $\sqrt{ }$ & $\mathrm{N}$ \\
\hline & Child independence & $\mathrm{N}$ & $\mathrm{N}$ & UI & $\mathrm{N}$ & $\mathrm{N}$ & $\mathrm{N}$ & $\mathrm{N}$ & Ps & $\sqrt{ }$ & $\mathrm{N}$ \\
\hline \multirow{11}{*}{ Assessment Method } & Multiple goals & VG & N/A & $\mathrm{F}$ & $\mathrm{P}$ & $\mathrm{E}$ & $\mathrm{G}$ & VP & $\mathrm{F}$ & $\mathrm{E}$ & $\mathrm{Y}$ \\
\hline & Relative weighting of goals & Via $\$$ & N/A & $\mathrm{L}$ & $\mathrm{P}$ & $\mathrm{E}$ & $\mathrm{F}$ & $\mathrm{N} / \mathrm{A}$ & $\mathrm{F}$ & $\mathrm{G}$ & $\mathrm{N}$ \\
\hline & Multi-faceted & G & N/A & $\mathrm{L}$ & $\mathrm{F}$ & VG & G & Ps & G & G & $\mathrm{G}$ \\
\hline & Measurable objectives (KPIs) & G & G & $P$ & N/A & G & G & N/A & G & G & $\mathrm{G}$ \\
\hline & Practicality of baseline data & $G$ & $G$ & $P$ & $\mathrm{~N} / \mathrm{A}$ & G & $G$ & $\mathrm{~N} / \mathrm{A}$ & $G$ & $\mathrm{G}$ & $\mathrm{P}^{3}$ \\
\hline & Practicality of computation & G & N/A & $P$ & N/A & G & $\mathrm{G}$ & N/A & $\mathrm{P}$ & $\mathrm{E}$ & $\mathrm{F}^{3}$ \\
\hline & Comprehensibility & $\mathrm{G}$ & $\mathrm{E}$ & $\mathrm{L}$ & N/A & VG & VG & N/A & G & G & $\mathrm{G}$ \\
\hline & Defensibility & $\mathrm{G}$ & $\mathrm{E}$ & VP & $\mathrm{F}$ & $\mathrm{E}$ & $G$ & $\mathrm{~F}$ & $G$ & $\mathrm{E}$ & $\mathrm{G}$ \\
\hline & Valid assumptions & $\mathrm{G}$ & VG & $P$ & $\mathrm{P}$ & VG & $\mathrm{F}$ & N/A & $\mathrm{G}$ & $\mathrm{E}$ & $\mathrm{G}$ \\
\hline & Not biased against long-term & $\mathrm{F}$ & $E$ & $\mathrm{~F}$ & $P$ & VG & $\mathrm{F}$ & $\mathrm{P}$ & $G$ & $E$ & G \\
\hline & $\begin{array}{l}\text { National government } \\
\text { participation }\end{array}$ & $\mathrm{E}$ & $G$ & VP & $P$ & $E$ & $G$ & $P$ & $P$ & VG & $G$ \\
\hline Legend: & $\begin{array}{l}\mathrm{Y}=\text { Yes } \\
\mathrm{N}=\text { No } \\
\text { LDN = London } \\
\text { Ps = Project specific } \\
\mathrm{Ra}=\text { Rural areas } \\
\text { Uk = Unknown } \\
\text { UI = Unlikely }\end{array}$ & \multicolumn{3}{|c|}{$\begin{array}{l}E=\text { Excellent } \\
\text { VG = Vary Good } \\
G=\text { Good } \\
F=\text { Fair } \\
P=\text { Poor } \\
V P=\text { Very Poor } \\
L=\text { Likely } \\
\text { N/A = Not Applicable }\end{array}$} & \multicolumn{7}{|c|}{$\begin{array}{l}{ }^{1} \text { Contracting in London, otherwise socially necessary } \\
\text { services only } \\
{ }^{2} \text { national required, local content not allowed } \\
{ }^{3} \text { pertains to developing countries }\end{array}$} \\
\hline
\end{tabular}


Two observations are made, about the practical limits of formal assessment procedures, despite their apparent theoretical advantages in more equitable, consistent and inclusive results.

1. The formal assessment assumes cooperative government at all levels, each willing to participate in good faith and abide by the outcomes of the alternatives analyses and public participation (although it needs to be mentioned that public participation, in many instances, could benefit from refinement, including taking better advantage of social media and the internet). An example is the aforementioned SUTP's very logical planning cycle for a Sustainable Urban Mobility Plan. Step 7 is "Agree on clear responsibilities and allocate funding" (SUTP, 2014). In reality, there is a chronic lack of agreement in many jurisdictions.

2. There can be other laws or public policies adverse to laws that dictate a PT assessment procedure. An important feature of an effective procedure is that it mandates an array of alternatives be explored. An adverse law or public policy can take promising alternatives off of the table.

\section{Some Suggestions for Further Improvements}

There is a school of thought that the CBA should continue to be the dominant form of evaluation, albeit with continual refinements. The Organization for Economic Cooperation and Development (OECD) recently convened a workshop of CBA experts to discuss the future of transport assessment (Veryard, 2016). Amongst their conclusions, they thought it important to restate this quote (Dobes and Bennett, 2009):

"In MCA, objectives are generally weighted according to their priority for the decision maker (and to an extent their degree of overlap with other objectives). While guidelines are available to support MCA decision processes, economists are generally skeptical of its application due to issues of double counting, arbitrary implicit valuations, lack of viability thresholds, and "gaming" the system".

As for trying to evaluate several factors simultaneously (Dobes and Bennett, 2009):

"Several participants argued that in such instances, it is preferable to instead highlight these relevant impacts qualitatively alongside the CBA result, as is the practice in the U.K. Appraisal Summary, rather than adding a false sense of precision with the integrated result of the MCA approach".

The authors feel that similar accusations can be made about the CBA. This is especially so when forecasts are involved and future costs must be estimated. It is indeed an improvement to add qualitative relevant impacts alongside the CBA result. Thus, MCA should not be abandoned, but seen as valuable extension of CBA, as demonstrated in the Cape Town case, where all traditional CBA values were included in the assessment and in the new Danish SUSTAIN method where a probabilistic form of CBA is included. 
The suggested MCA enhancement might come in the form of an AHP, a decisionmaking method that is already widely used in the marketing profession and in some corporate internal decisions involving major investments. It has shown promise, even for application in less developed countries, but there are many issues to overcome, such as lack of data and experts on needed topics (Khademi et al., 2014). The Danish (REMBRANDT based) method was the only one listed in our sampling that requires the use of anything similar to AHP. Its appeal is that it is intuitive and, thus, can be understood without deep mathematical capability. It addresses the problem of incommensurability of the various goals, as well as the issue of different importance of these goals.

Discounting also needs further refinement. The use of differential discounting between actual money expenditures and monetized values could have a profound impact on project selection. Martin Weitzman (1994) advocates use of discount rates that become smaller as the distance into the future becomes longer. It falls to $1 \%$ for 76 to 200 years into the future. Bruun (2013) discusses the possibility of using no, or a very low discount rate, for any monetized environmental costs and benefits while continuing to use the customary discount rate for actual monetary expenditures on civil works and equipment. This is based on the argument that sustainability, in the strictest definition, requires that environmental impacts to future generations be counted as equal to the current.

Finally, the type of delivery method that is appropriate for a particular project remains a contentious subject. This is unfortunate as the entire feasibility and affordability of a particular alternative may depend upon whether and how the private sector participates in the various parts of the lifecycle, from initial funding through the construction phase and daily operation. Tang and Lo (2010) provide an example of three "influence diagrams," one each for the build, fund, and own decisions. For each of these, there are three possible agents, the railway operator, the government or a property developer. Conditional probabilities are then used in this interaction chain to estimate which agent is likeliest to give the best outcome for each of these decisions. In the spirit of trying to systematize and quantify important relationships between parties to help select the best possible candidate project alternatives, perhaps influence diagrams merit more widespread use.

\section{Concluding Remark}

This paper describes a wide range of assessment tools, and implementations from all over the world. Transport project assessment is specific to local policies and conditions. However, the authors are of the opinion that national governments and local authorities can learn from the experience of others. Furthermore, more inclusive assessment methods, such as MCA and SLA and packages that unify qualitative and quantitative factors, like AHP/REMBRANDT, are preferred over traditional CBA alone. For suggested criteria, see Table 4. In practice, analytic MCA and SLA methods would have to condense these criteria into a few key higher level groups. 
It is worthwhile to follow current events as new methods actually combine the CBA with MCA, such as the Cape Town case and SUSTAIN. This overcomes many of the shortcomings of the more traditional and simpler methods. They show promise for adaption to a variety of circumstances, particularly in an era where participation at levels - public, professional and elected officials, is becoming easier and more efficient.

This paper does describe positive and negative aspects of various assessment tools. Although many, if not all, methods/tools have challenges, the authors are of the opinion that a broad and inclusive assessment of PT investment project is a must and that the ad-hoc investments witnessed around the world should be avoided.

\section{References}

AASHTO. 2014. "Safetea LU versus Map 21 A Comparison. http://map21.transportation. org/Pages/ Safetealuvsmap21.aspx, accessed 19 September 2014.

Abley, Steve, Paul Durdin and Malcolm Douglass. 2010. Integrated Transport Assessment Guidelines, Report 422, Land Transport New Zealand. http://www.nzta. govt.nz/resources/research/reports/422

Alberta Government. 2016. GreenTRIP Green Transit Incentives Program: Procedures and Guidelines. http://www.transportation.alberta.ca/Content/docType5409/ Production/GreenTRIPProceduresandGuidelines.pdf

ADB (Asian Development Bank). 2009. Changing Course: A New Paradigm for Sustainable Urban Transport. https://www.adb.org/sites/default/files/ publication/27552/new-paradigm-transport.pdf

Banai R. 2006. Public Transportation Decision-Making: A Case Analysis of the Memphis Light Rail Corridor and Route Selection with Analytic Hierarchy Process, Journal of Public Transportation, Volume 9, Issue 2, pp. 1-24.

Bell, John R. 2010. “LaHood Announces Adoption of Long-Sought 'New Starts' Criteria," Passenger Transport, January 18.

Beukers, E., L. Bertolini and M. Te Brömmelstroet. 2012. Why Cost Benefit Analysis is Perceived as a Problematic Tool for Assessment of Transport Plans: A Process Perspective, Transportation Research Part A, Vol 46, pp 68-78.

Bruun, E.C., 2013. Better Public Transit Systems: Analyzing Investments and Performance, 2nd Edition, Chapter 8, Oxon, U.K.: Routledge.

Bundesminister für Verkehr. 1996. Anleitung für die Standartisierte Bewertung von Verkehrswegeinvestitionen des ÖPNV und Hinweise zum Rahmenantrag Schriftreihe des Bundesministers für Verkehr, Heft 51 (German).

CBC News, 2016. Union Pearson Express fare slashed from \$27.50 to \$12: Airport train has struggled to make ridership goals since summer launch, Feb 23. Accessed 8 October 2016. http://www.cbc.ca/news/canada/toronto/union-pearson-expressprice-1.3459482 
CUTA (Canadian Urban Transport Association). 2011. Federal Provincial and Territorial Public Transit Funding Programs in Canada.

Dobes, L. and J. Bennett. 2009. Multi-Criteria Analysis: "Good Enough" for Government Work? Agenda: A Journal of Policy Analysis and Reform, Vol 16, Issue 3, pp. 7-29.

Figueira, J., G. Salvatore and M. Ehrgott, Editors, 2005. Multiple Criteria Decision Analysis: State of the Art Surveys, Springer, New York.

Godavarthy R.P., J. Mattson, D. Peterson and J. Hough. 2015. Developing a Method for Assessing National Demand-Response Transit Level of Service, Journal of Public Transportation, Vol 18, Issue 4, pp. 1-15.

Hajkowicz S. and A. Higgins, 2008. A Comparison of Multiple Criteria Analysis Techniques for Water Resource Management. European Journal of Operational Research, Vol 184, Issue 1, 1 January 2008 pp. 255-265.

Hawas Y.E., B. Khan, N. Basu, 2012. Evaluating and Enhancing the Operational Performance of Public Bus Systems Using GIS-based Data Envelopment Analysis, Journal of Public Transportation, Vol 15, Issue 2, pp. 19-44.

Holian, M. and R. McLaughlin. 2016. Benefit-Cost Analysis for Transportation Planning and Public Policy: Towards Multimodal Demand Modeling. MTI Report 12-4, Mineta Transportation Institute. San Jose, CA. USA. http://transweb.sjsu.edu/PDFs/ research/1203-benefit-cost\%20analysis\%20for\%20transportation-planning-andpublic-policy-toward-multimodal-demand-modeling.pdf

Howarth, R.B., 2003. Discounting and Sustainability: Towards Reconciliation, International Journal of Sustainable Development, Vol 6, issue 1, pp. 87-97.

UITP (International Association for Public Transport). 2009. Assessing the Benefits of Public Transport, A UITP Position Paper, pp. 1-6.

Jensen, A.V, I. Ambrasaite, K.B. Salling, M.B. Barfod and S. Leleur. 2012. "The EcoMobility Modelling Framework for Sustainable Transport Planning." Chapter 9 in Rethinking Transport in the Øresund Region: Policies, Strategies and Behaviours, edited by C-M. Carlsson, T. Emtairah, B. Gammelgaard, A.V. Jensen and A. Thidell. Lund, Sweden: Lund University, pp. 149-164.

Jensen, A.V., K.B. Salling, and S. Leleur. 2013. "The SUSTAIN Appraisal Framework: Flexible Decision Support for National Sustainable Transport Planning” extended version of paper presented at WCTR Conference, Rio de Janeiro, July.

Khademi, N., K. Behnia, and R. Saedi, 2014. Using Analytic Hierarchy/Network Process (AHP/ANP) in Developing Countries: Shortcomings and Suggestions, The Engineering Economist, Vol 59, pp. $2-29$.

Lo, H.K., W.H.K. Lam, S.C. Wong and J.M.Y. Leung. 2010. Editorial: Advanced Methods for Public Transport Management, Public Transport, Vol 2, pp. 1-3, DOI 10.1007/ s12469-010-0025-6. 
Martel J.M. and B, Matarazzo. 2005. Other Outranking Approaches. In: J. Figueira, G. Salvatore and M. Ehrgott, Editors, Multiple Criteria Decision Analysis: State of the Art Surveys, Springer, New York, pp. 197-262.

Ministry of Transportation (Ontario). 2009. VIVA Rapid Transit Construction Underway: McGuinty Government and Partners Adding More Transit In York Region, December 14.http://www.metrolinx.com/Docs/News/NR_York_Rapidways_COPO_ EN151209.pdf.

Mitric, S., 2008. Urban Transport for Development: Towards an Operationally-Oriented Strategy, Washington DC: World Bank.

Nationalrat Schweiz. 1986. Bundesbeschluss über den Leistungsauftrag 1987 an die schweiserischen Bundesbahnen und über Abgeltung ifrer gemeinschaftlichen Leistung, Art. 4, (S). Nijkamp, P., P. Rietveld and H. Voogd. 1990. Multicriteria Evaluation in Physical Planning, North Holland, Amsterdam, pp. 65-100.

Olivková, I., 2015. Model for Measuring Passenger Satisfaction and Assessing Mass Transit Quality, Journal of Public Transportation, Vol 18, Issue 3, pp. 52-70.

Paterson L. 2015. Evaluating the Regional Benefit/Cost Ratio for Transit State of Good Repair Investments, Journal of Public Transportation, Vol 18, Issue 3, pp. 15-28.

Phillips R.G. and M. Guttenplan. 2003. A Review of Approaches for Assessing MultiModal Quality of Service, Journal of Public Transportation, Vol 6, Issue 4, pp. 69-87.

Progressive Railroading. 2014. Montreal Transit Agency to Slow Phase-In of New Subway Cars. 30 October 2014.

Roberts, R. and P. Goodwin. 2002. Weight Approximations in Multi-Attribute Decision Models. Journal of Multi-Criteria Decision Analysis Vol 11, no. 6, pp. 291-303.

Sah, B.P., Choi, J. Sentihil, S, Babu B.M. and M. Vanderschuren (2008), Geographic Information Systems based Decision Support System for Transportation Planning in Maseru, Lesotho, Africa, 21st EAROPH World Congress and Mayors' Caucus, Oct. 21-24, 2008, Japan.

Salling K.B. and S. Leleur. 2011. Transport Appraisal and Monte Carlo Simulation by use of the CBA-DK Model, Transport Policy, Vol 18, pp. 236-245.

Salling, K.B. and S. Leleur. 2012. "Modelling of Transport Project Uncertainties: Feasibility Risk Assessment and Scenario Analysis" European Journal of Transportation Infrastructure Research Vol 12 no.1: 21-38. http://www.ejtir.tbm.tudelft.nl.

Schiefelbusch, M. 2015. Analyzing and Assessing the Experience of Traveling by Public Transport, Journal of Public Transportation, Vol 18, Issue 4, pp. 46-72.

Shergold, I. and G. Parkhurst. 2016. The Economic Benefits of Sustainable Urban Mobility Measures Independent Review of Evidence: Report, EVIDENCE Project, European Commission, Brussels. http://tinyurl.com/m36e4un. 
SUTP (Sustainable Urban Transport Project). 2014. SUTP Technical Document \# 13: Urban Mobility Plans - National Approaches and Local Practices. http://www.sutp. org/files/contents/documents/resources/B_Technical-Documents/GIZ_SUTP_ TD13_Urban-Mobility-Plans_EN.pdf.

Tang S. and H.K. Lo. 2010. "Assessment of Public Private Partnership Models for Mass Rail Transit - an Influence Diagram Approach" Public Transport Vol 2: pp. 111-134, DOI 10.1007/s12469-010-0023-8.

TIDE (Transport Innovation Deployment for Europe). 2013. Impact Assessment Handbook: Practitioners' Handbook for Cost Benefit and Impact Analysis of Innovative Urban Transport Measures, TIDE Project, European Commission, Brussels. http://www.tide-innovation.eu/en/upload/Results/T495_TIDE-AssessmentHandbook-Lite.pdf.

U.K. DfT (Department of Transport). 2006a. Transport Analysis Guidance, Integrated Transport Economics and Appraisal, Department for Transport. https://www.gov. uk/guidance/transport-analysis-guidance-webtag, accessed 10 October 2016.

U.K. DfT (Department of Transport). 2006b. Putting Passengers First: The Government's proposals for a modernised national framework for bus services. December. London. http://webarchive.nationalarchives. gov.uk/20090806013054/http:/www. dft.gov.uk/pgr/regional/buses/secputtingpassengersfirst/pdfputtingpassfirst.pdf.

U.K. DfT (Department of Transport). 2009. NATA Refresh: Appraisal for a Sustainable Transport System - New Approach to Transport Appraisal, http://bettertransport. org.uk/sites/default/files/dft_natarefreshApril_2009.pdf.

U.K. DfT (Department for Transport). 2012. Reforming our Railways: Putting the Customer First, Presented to Parliament by the Secretary of State for Transport, March. https://www.gov.uk/government/uploads/system/uploads/attachment_ data/file/4216/reforming-our-railways.pdf.

U.S. General Accounting Office. 1999. FTA's Progress in Developing and Implementing a New Starts Evaluation Process. Report RCED-99-113. Washington, D.C.: U.S. Government Printing Office.

Vanderschuren, M., A. Frieslaar and T. Lane. 2008. Assessment of the Improvement Strategies for the N1 Corridor between Bellville and Cape Town, Paper for the South African Transport Conference, Pretoria, July.

Veryard, D. 2016. Quantifying the Socio-Economic Benefits of Transport: Roundtable Summary and Conclusions. Discussion Paper • 06, International Transport Forum, Paris, France. http://www.itf-oecd.org/sites/default/files/docs/summary-roundtable-socio-economic-benefits-transport.pdf.

Voogd, H. 1982. Multi-Criterion Evaluation with Mixed Qualitative and Quantitative Data, Environment and Planning Bulletin 9, pp. 221-236. 
Voogd, H. 1983. Multi-Criteria Evaluation for Urban and Regional Planning, Pion, London.

Watson, R. 2001. The Effect of Railway Privatization on Train Planning: a Case Study of the UK. Transport Reviews, Vol. 21, No. 2, pp. 181-193.

Weitzman, M.L. 1994. “On the Environmental Discount Rate," Journal of Environment and Management, Vol 26 No. 2, pp. 200-209. 